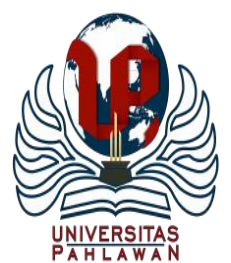

Edukatif : Jurnal Ilmu Pendidikan Volume 3 Nomor 3 Tahun 2021 Halm 1029 - 1037

EDUKATIF: JURNAL ILMU PENDIDIKAN

Research \& Learning in Education

https://edukatif.org/index.php/edukatif/index

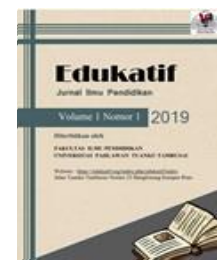

\title{
Integrasi Model Inkuiri Terbimbing Dan Pendekatan Flipped Classroom Pada Pembelajaran Materi Sifat Koligatif Larutan Untuk Siswa Kelas XII SMA/MA
}

\author{
Wilda Putri Waer ${ }^{1}$, Mawardi Mawardi ${ }^{2 \varpi}$ \\ Universitas Negeri Padang, Indonesia ${ }^{1}$ \\ Universitas Negeri Padang, Indonesia ${ }^{2}$ \\ E-mail : putrywaer07@gmail.com ${ }^{1}$, mawardianwar@ fmipa.unp.ac.id ${ }^{2}$
}

\begin{abstract}
Abstrak
Mewabahnya virus Covid-19, yang ditetapkan oleh WHO sebagai pandemi global pada awal Maret 2020, menyebabkan terjadinya perubahan yang signifikan terhadap banyak aspek di dunia, termasuk Indonesia, diantaranya dalam aspek pendidikan. Pemerintah mengambil kebijakan pembelajaran beralih dari sistem luring ke sistem online (daring). Untuk menghadapi perubahan itu, maka guru sebagai salah satu komponen dalam pendidikan, perlu mempersiapkan bahan ajar agar bisa digunakan dalam pembelajaran online. Penelitian ini bertujuan untuk mengembangkan dan mengungkap tingkat validitas dan kepraktisan integrasi model inkuiri terbimbing dengan pendekatan flipped classroom pada materi sifat koligatif larutan yang dikembangkan untuk pembelajaran di sekolah menengah atas. Jenis penelitian yang dilakukan adalah Research and Development (R\&D) dengan model pengembangan Plomp. Subjek penelitian ini adalah dosen kimia Universitas Negeri Padang, guru kimia SMAN 8 Padang, dan siswa kelas XII IPA SMAN 8 Padang. Instrumen yang digunakan adalah lembar validasi, dan lembar kepraktisan. Validasi dilakukan oleh 2 dosen kimia, 1 guru kimia dan satu banding satu oleh 3 siswa. Uji kepraktisan dilakukan terhadap 15 siswa kelas XII IPA SMAN 8 Padang. Data validitas yang diperoleh sebesar 0,81 pada kategori valid dan uji kepraktisan dengan nilai 87 pada kategori kepraktisan sangat tinggi. Hasil penelitian tersebut menunjukkan bahwa model ini valid dan praktis.
\end{abstract}

Kata Kunci: inkuiri terbimbing, flipped classroom, sifat koligatif larutan.

\section{Abstract}

The Covid-19 virus caused major changes around the world, including Indonesia. So that WHO declared this outbreak a global pandemic in March 2020. This policy caused learning to shift to an online system. This study aims to develop and reveal the validity and practicality of the integration of the guided inquiry model with the flipped classroom approach on the colligative nature of the solutions developed for learning in secondary schools. The type of research carried out is $(R \& D)$ with the Plomp development model. The subjects of this study were a lecturer in chemistry at the State University of Padang, a chemistry teacher at SMAN 8 Padang, and students of class XII IPA at SMAN 8 Padang. The instruments used were the validation sheet and the practicality sheet. Validation was carried out by 2 chemistry lecturers, 1 chemistry teacher, and one to one by 3 students. The practicality test was carried out on 15 students of class XII IPA at SMAN 8 Padang. The validity data obtained was 0.81 in the valid category and the practicality test with a value of 87 in the very high practicality category. The results of these studies indicate that this model is valid and practical.

Keywords: guided inquiry, flipped classroom, the colligative nature of the solution.

Copyright (c) 2021 Wilda Putri Waer, Mawardi Mawardi

$\triangle$ Corresponding author

Email : mawardianwar@fmipa.unp.ac.id

DOI : https://doi.org/10.31004/edukatif.v3i3.498

ISSN 2656-8063 (Media Cetak)

ISSN 2656-8071 (Media Online)

Edukatif : Jurnal Ilmu Pendidikan Vol 3 No 3 Tahun 2021 p-ISSN 2656-8063 e-ISSN 2656-8071 
1030 Integrasi Model Inkuiri Terbimbing Dan Pendekatan Flipped Classroom Pada Pembelajaran Materi Sifat Koligatif Larutan Untuk Siswa Kelas XII SMA/MA - Wilda Putri Waer, Mawardi Mawardi

DOI: https://doi.org/10.31004/edukatif.v3i3.498

\section{PENDAHULUAN}

Mewabahnya suatu virus yang bernama Corona atau dikenal dengan istilah Covid-19 (Corona Virus diseases-19) menyebabkan terjadinya perubahan yang sangat besar terhadap segala aspek di dunia. Sehingga WHO menetapkan wabah ini sebagai pandemi global pada awal Maret 2020. Kebijakan ini juga memberikan dampak pada bidang pendidikan, yaitu beralihnya sistem pembelajaran menjadi sistem online (daring). Pembelajaran daring bukan hal mudah untuk dilakukan oleh pendidik dan peserta didik. Sehingga dibutuhkan model dan sistem pembelajaran yang cocok untuk dilakukan pada keadaan saat ini, agar siswa termotivasi untuk belajar lebih giat serta mendapatkan hasil belajar yang maksimal (Wijanarko, 2017).

Satu diantara model pembelajaran yang memanfaatkan teknologi yaitu Blended Learning. Blended Learning merupakan pembelajaran yang terpusat pada peserta didik, dan memanfaatkan teknologi untuk mengembangkan suasana kelas yang efisien, dan lingkungan belajar yang berorientasi pada keberhasilan dalam belajar (Chaeruman, 2019). Pembelajaran ini merupakan perpaduan dari pembelajaran sinkronos dan asinkronos. Salah satu bagian dari blended learning adalah flipped classroom. Belajar dengan Sistem flipped classroom adalah belajar dengan membalik apa yang biasanya terjadi di dalam kelas dan di luar kelas. Flipped classroom adalah pembelajaran yang berpusat pada siswa (Fautch, 2015). Dalam penelitian (Freeman \& Herreid, 2013), pembelajaran menggunakan flipped classroom dapat meningkatkan hasil belajar siswa dibandingkan dengan pembelajaran yang biasa dilakukan.

Dalam proses pembelajaran siswa diharapkan untuk dapat aktif dan kolaboratif. Salah satu model pembelajaran yang mendukung yaitu model pembelajaran inkuiri terbimbing. Inkuiri terbimbing adalah model pembelajaran aktif, di mana siswa dapat membangun pemahamannya sendiri dengan menghubungkannya dengan pengetahuan sebelumnya (Hanson, 2005). Dengan menggunakan model inkuiri terbimbing siswa dapat mengembangkan kemampuan pemecahan masalah dan berpikir kritisnya (Aumi \& Mawardi, 2021). Inkuiri terbimbing dapat merangsang, mengajar dan mengajak siswa untuk berpikir lebih tinggi untuk menemukan konsep secara mandiri dari berbagai masalah, hal ini diungkapkan oleh (Danczak et al., 2020; Kardena \& Mawardi, 2020). Dalam model ini peserta didik diberi kesempatan untuk berfikir kritis serta saling membantu dengan teman yang lain. Pembelajaran inkuiri terbimbing berfokus pada kemandirian siswa untuk mencari dan menemukan (Akkuzu \& Uyulgan, 2017; Yani et al., 2019). Inkuiri terbimbing merupakan model pembelajaran yang efektif dalam bidang kimia, karena dapat mendorong siswa untuk menggunakan sumber belajar dan bekerja dalam kelompok (Aini et al., 2019). Adapun langkah-langkah atau tahapan dari kegiatan pembelajaran inkuiri terbimbing yaitu; Orientasi, Eksplorasi dan Pembentukan Konsep, Aplikasi, dan Penutup. Pada penelitian yang dilakukan oleh (Mawardi et al., 2020) menggunakan lembar kegiatan siswa (LKS) berbasis inkuiri terbimbing dapat meningkatkan kemampuan siswa untuk menganalisis dan mengevaluasi.

Pada penelitian yang telah dilakukan (Nurhayati et al., 2017) pembelajaran dengan menggunakan model inkuiri blended learning strategi flipped classroom lebih menekankan pada proses penemuan, siswa mencari dan menemukan sendiri konsep yang dipelajari, dan peran guru adalah sebagai fasilitator selama belajar dalam lingkungan campuran antara tatap muka di kelas dan secara online melalui moodle. Selain itu pembelajaran menggunakan flipped classroom yang dipadukan dengan Collaborative Problem Solving membuat siswa terbiasa bertukar ide dan pendapat yang dapat melatih kemampuan berpikir kritis siswa menjadi lebih baik (Karyadi et al., 2020).

Berdasarkan latar belakang diatas peneliti ingin melakukan penelitian integrasi model inkuiri terbimbing dan pendekatan flipped classroom pada materi sifat koligatif larutan untuk siswa kelas XII SMA/MA. Model pembelajaran ini sebelumnya belum banyak diterapkan terutama di daerah Sumatera Barat, sehingga nantinya penelitian ini diharapkan bisa menjadi salah satu referensi untuk menerapkan model pembelajaran tersebut yang efektif dan praktis untuk dilakukan secara online selama pandemi dan kondisi khusus lainnya serta dapat 
1031 Integrasi Model Inkuiri Terbimbing Dan Pendekatan Flipped Classroom Pada Pembelajaran Materi Sifat Koligatif Larutan Untuk Siswa Kelas XII SMA/MA - Wilda Putri Waer, Mawardi Mawardi

DOI: https://doi.org/10.31004/edukatif.v3i3.498

mendukung pembelajaran di era 4.0. Model pembelajaran ini menggunakan fasilitas pendukung berupa Learning Management System (LMS) yaitu Edmodo dan Zoom meeting.

\section{METODE}

Jenis penelitian yang dilakukan adalah Research and Development (R\&D) dengan model pengembangan Plomp, yang memiliki beberapa tahapan yaitu; preliminary research, prototyping phase dan assessment phase. Penelitian dilakukan untuk menghasilkan suatu produk berupa integrasi model inkuiri terbimbing dan pendekatan flipped classroom pada materi sifat koligatif larutan untuk siswa kelas XII SMA/MA.

Pada tahap preliminary research terdapat beberapa analisis yang dilakukan, yaitu analisis kebutuhan dan konteks, studi literatur, dan analisis pengembangan kerangka konsep. Tahap ini bertujuan untuk menentukan dan mengidentifikasi syarat-syarat dalam penelitian integrasi model inkuiri terbimbing dan pendekatan flipped classroom pada materi sifat koligatif larutan untuk siswa kelas XII SMA/MA. Pada tahap ini dilakukan analisis masalah di sekolah, berdasarkan observasi dan wawancara dengan guru, serta referensi berbagai literatur untuk menyelesaikan masalah pembelajaran yang terjadi selama COVID-19 di Indonesia dan juga di berbagai negara lain yang terdampak COVID-19. Sehingga menghasilkan sistem pembelajaran berbasis model inkuiri terbimbing dan flipped classroom.

Pada Tahap prototyping phase dilakukan perencanaan pembentukan prototype dengan merealisasikan produk berupa model pembelajaran inkuiri terbimbing dan pendekatan flipped classroom pada materi sifat koligatif larutan untuk siswa kelas XII SMA/MA. Pada tahap ini dilakukan siklus penelitian mikro yaitu analisis, perancangan, evaluasi dan revisi. Pada tahap ini, setelah perancangan prototipe 1 selanjutnya dilakukan evaluasi formatif. Evaluasi formatif dilakukan dalam bentuk evaluasi diri yang hasil revisinya menghasilkan prototipe 2. Selanjutnya penilaian ahli dan evaluasi one to one, yang bertujuan untuk mengetahui validitas model yang dikembangkan. Validasi dilakukan oleh 2 dosen kimia, 1 guru kimia dan Evaluasi one to one dilakukan dengan melakukan wawancara kepada 3 siswa SMA kelas XII. Setelah dilakukan revisi maka akan dihasilkan prototipe 3. Kemudian Dari hasil prototipe 3 yang telah valid, dilakukan evaluasi dengan cara uji coba kelompok kecil yang terdiri dari enam orang peserta didik dengan tiga tingkat kemampuan dari rendah, sedang hingga tinggi dengan menggunakan angket untuk mengetahui tingkat kepraktisan prototipe 3. Jika masih diperlukan perbaikan maka dilakukan revisi sesuai saran dari peserta didik. Revisi tersebut bertujuan untuk meningkatkan kualitas sehingga menjadi prototipe IV yang praktis.

Pada tahap assessment phase dilakukan evaluasi untuk melihat apakah produk yang dihasilkan dapat digunakan dalam prakteknya di lapangan. Uji lapangan (field test) dilakukan pada tahap ini sehingga tingkat praktikalitas dari produk didapatkan. Jika perlu perbaikan maka akan dilakukan revisi sesuai saran-saran dari guru dan peserta didik sehingga menghasilkan prototipe final berupa buku panduan dan rancangan pengembangan model pembelajaran inkuiri terbimbing dan pendekatan flipped classroom pada materi sifat koligatif larutan yang telah valid dan praktis.

\section{HASIL DAN PEMBAHASAN}

Kondisi pandemi saat ini yang memindahkan pembelajaran kimia menjadi online dapat kita ketahui melalui tahap preliminary research yang dilakukan di SMAN 8 Padang. Pada mata pelajaran kimia salah satu materi yang dipelajari secara online akibat pandemi ini adalah sifat koligatif larutan. Setelah melakukan studi literatur, didapatkan diantaranya metode pembelajaran secara flipped classroom dan inkuiri terbimbing yang merupakan salah satu solusi dalam melaksanakan pembelajaran pada masa pandemi COVID-19 saat ini (Nerantzi, 2020). Maka dari itu dikembangkan model pembelajaran inkuiri terbimbing dengan pendekatan flipped classroom. Sifat koligatif larutan merupakan salah satu mata pelajaran yang memiliki konsep yang 
1032 Integrasi Model Inkuiri Terbimbing Dan Pendekatan Flipped Classroom Pada Pembelajaran Materi Sifat Koligatif Larutan Untuk Siswa Kelas XII SMA/MA - Wilda Putri Waer, Mawardi Mawardi

DOI: https://doi.org/10.31004/edukatif.v3i3.498

luas, sehingga pada umumnya siswa menemukan masalah pada saat mempelajari materi tersebut, kemudian materi yang telah disiapkan akan divalidasi terlebih dahulu oleh ahlinya.

Berikut tahapan pembelajaran model inkuiri terbimbing dan pendekatan flipped classroom

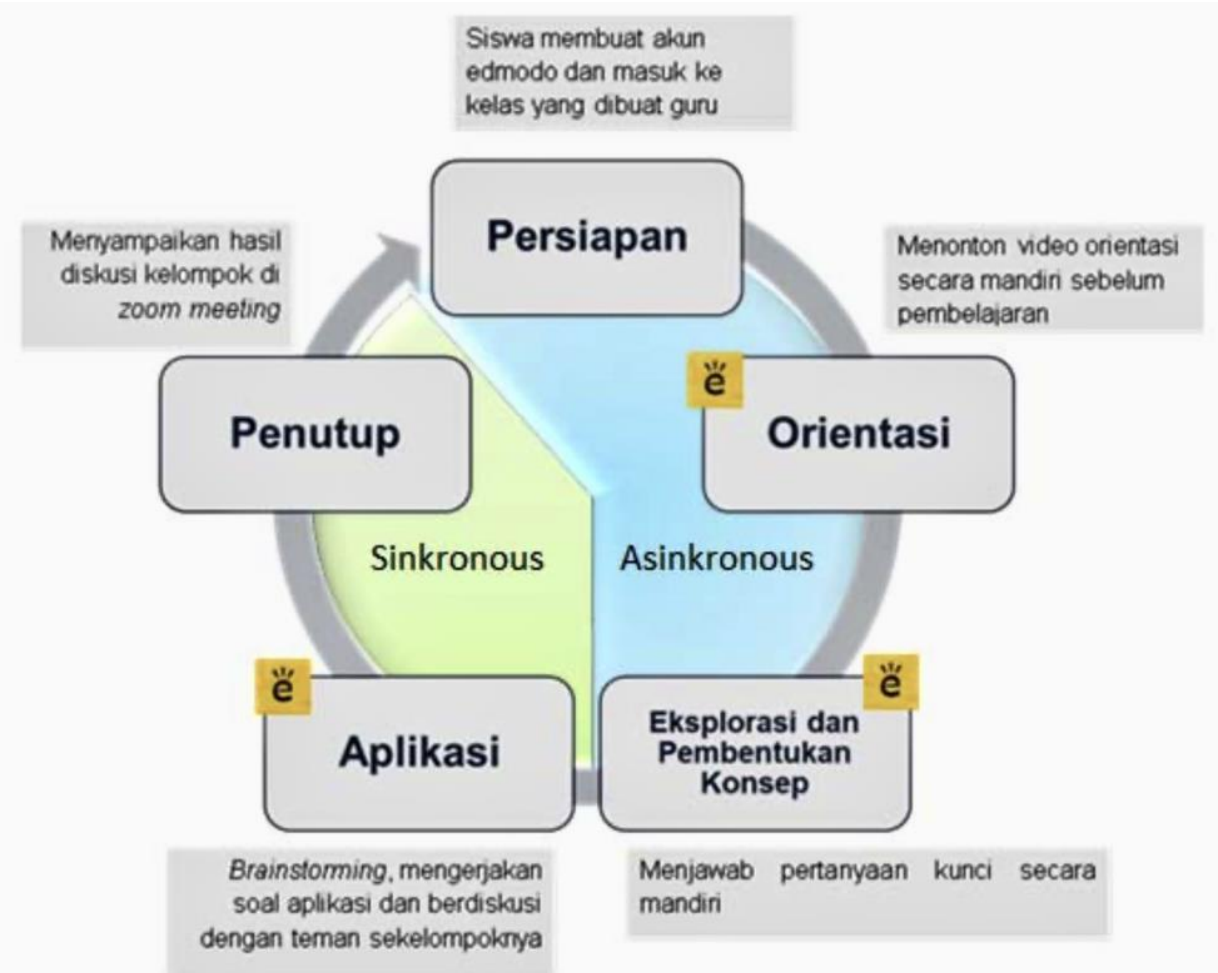

Gambar 1. Tahapan Pembelajaran Model Inkuiri Terbimbing Dan Pendekatan Flipped Classroom (Aumi \& Mawardi, 2021)

Inkuiri terbimbing berbasis flipped classroom dilakukan melalui dua tahap pembelajaran yaitu sinkronos dan asinkronos (Watson et al., 2020). Dimana pada kedua tahap tersebut akan digunakan model pembelajaran inkuiri terbimbing yang terdiri dari orientasi, eksplorasi dan pembentukan konsep, aplikasi serta penutup. Tahap orientasi, eksplorasi dan pembentukan konsep serta aplikasi akan dilakukan secara asinkronos, dengan menggunakan LMS Edmodo sedangkan penutup akan dilakukan secara tatap muka di kelas (zoom meeting) dapat dilihat pada (Gambar 1). Sebelum pembelajaran dimulai, guru terlebih dahulu mempersiapkan materi dan mempersiapkan siswa untuk mulai belajar secara online, dan siswa akan diberikan tugas sebelum masuk ke kelas. Dan saat di kelas siswa dan guru akan membahas tugas-tugas yang telah diberikan sebelumnya.

Orientasi. Pada tahap ini siswa akan menonton video yang telah diberikan oleh guru, siswa dapat mengakses video melalui Edmodo, dan siswa dapat menonton video kapanpun dan dimanapun. Guru membuat videonya sendiri. Video pembelajaran berisi tujuan pembelajaran yang ingin dicapai siswa, motivasi serta pengetahuan awal untuk menghubungkan materi sebelumnya dengan materi yang akan dipelajari.

Pertanyaan kunci dan pembentukan konsep. Setelah menonton video, siswa diberi model, model tersebut dapat berupa gambar, grafik, tabel, dll. Berdasarkan model tersebut diberikan pertanyaan kunci, yang berfungsi untuk mengarahkan siswa menemukan konsepnya sendiri.

Aplikasi. Setelah siswa menemukan konsep, siswa diberi pertanyaan untuk menguji pemahaman konsep siswa. Pertanyaan-pertanyaan tersebut akan memungkinkan siswa untuk membangun kepercayaan diri dan memiliki pemahaman konsep yang kuat. Pada tahap ini siswa dapat melakukan diskusi dengan teman kelompoknya masing-masing. 
1033 Integrasi Model Inkuiri Terbimbing Dan Pendekatan Flipped Classroom Pada Pembelajaran Materi Sifat Koligatif Larutan Untuk Siswa Kelas XII SMA/MA - Wilda Putri Waer, Mawardi Mawardi

DOI: https://doi.org/10.31004/edukatif.v3i3.498

Penutup. Siswa memulai pembelajaran pada periode sinkronos, dimana guru akan mereview konsep yang diperoleh siswa, dan siswa dapat mengkonfirmasikan konsep tersebut. Di kelas siswa akan melaporkan hasil diskusi dan soal yang telah dikerjakan sebelumnya. Guru akan memfasilitasi selama masa pembelajaran, dan pembenaran konsep jika diperlukan.

Pada tahap pengembangan atau pembuatan prototipe dilakukan perencanaan pembentukan prototype dengan merealisasikan produk berupa model pembelajaran inkuiri terbimbing dan pendekatan flipped classroom pada materi sifat koligatif larutan untuk kelas XII SMA/MA. Hal-hal yang dilakukan pertama kali untuk membuat prototipe 1 yaitu; 1) membuat desain pembelajaran dengan menggunakan inkuiri terbimbing, 2) menentukan model yang sesuai dengan tujuan pembelajaran (model dapat berupa gambar, grafik, tabel data, video, dll.), 3) membuat pertanyaan kunci berdasarkan model yang diharapkan untuk mendapatkan konsep, 4) membuat pertanyaan dan latihan, dan 5) berkonsentrasi pada bagian sintaks inkuiri terbimbing di Edmodo.

Model pembelajaran yang dikembangkan adalah pembelajaran inkuiri terbimbing yang disajikan dalam bentuk flipped classroom. Pembelajaran ini mengandung dua pengaturan, yaitu synchronous dan asynchronous. Pembelajaran asinkron dilaksanakan pada tahapan persiapan, orientasi, dan eksplorasi dan pembentukan konsep. Sedangkan pembelajaran sinkron dilakukan pada tahap penerapan dan penutupan. Tahap asinkron dilakukan dengan menggunakan LMS Edmodo, sedangkan tahap sinkron dilakukan dengan menggunakan zoom meeting. Dengan adanya

Prototipe 1 yang sudah dibuat dilakukan evaluasi formatif berupa evaluasi diri, jika didapatkan kekurangan maka dilakukan revisi sehingga menghasilkan prototipe 2. Pada (Plomp \& Nieveen, 2007) dalam penelitian dan pengembangan harus didasarkan pada state of art knowledge. Untuk mendapatkan tingkat validasi dari model yang dikembangkan maka dilakukan evaluasi pada penilaian ahli dan evaluasi perorangan yang dilakukan terhadap tiga siswa, dari evaluasi perorangan dapat diketahui suara pada video orientasi, bahasa yang digunakan dan pertanyaan kunci yang diberikan jelas dan dapat dipahami oleh siswa. Dari hasil wawancara, saran yang diberikan siswa adalah bahwa model (gambar) perlu ditambahkan beberapa informasi lagi yang memudahkan siswa dalam mengeksplorasi gambar. Dari uji validitas diketahui nilai yang diperoleh 0.81 termasuk valid kategori. Hal ini menunjukkan bahwa dari segi kelayakan isi, konstruksi, bahasa dan grafik model inkuiri terbimbing dan pendekatan flipped classroom yang dikembangkan memiliki kategori yang valid, validasi juga dilakukan oleh tinjauan ahli. apabila masih didapatkan kekurangan atau kesalahan maka dilakukan revisi dalam prototipe 2 sehingga menghasilkan prototipe 3 yang telah valid.

Hasil validasi akan dihitung menggunakan rumus Aikens V, sebagai berikut:

$$
V=\frac{\sum s}{n(c-1)}
$$

Tabel 1 Hasil Validitas Menurut Penilaian Ahli

\begin{tabular}{|c|l|c|c|}
\hline No & \multicolumn{1}{|c|}{ Aspek Dinilai } & Nilai & Kategori \\
\hline 1 & Kelayakan Konten & 0,78 & Valid \\
\hline 2 & Kelayakan Konstruksi & 0,86 & Valid \\
\hline 3 & Kebahasaan & 0,78 & Valid \\
\hline 4 & Grafik & 0,83 & Valid \\
\hline \multicolumn{2}{|c|}{ Rata-rata } & 0,81 & Valid \\
\hline
\end{tabular}


1034 Integrasi Model Inkuiri Terbimbing Dan Pendekatan Flipped Classroom Pada Pembelajaran Materi Sifat Koligatif Larutan Untuk Siswa Kelas XII SMA/MA - Wilda Putri Waer, Mawardi Mawardi

DOI: https://doi.org/10.31004/edukatif.v3i3.498

Dari hasil Prototipe 3 yang telah valid dilakukan evaluasi dengan cara uji coba kelompok kecil dengan menggunakan angket untuk mengetahui tingkat kepraktisan prototipe. Evaluasi kelompok kecil ini dilakukan pada 15 siswa, yang bertujuan untuk melihat kepraktisan model yang dihasilkan. Dari pengujian tersebut terlihat bahwa nilai kepraktisan yang diperoleh adalah 87 dengan kategori kepraktisan sangat tinggi. Berdasarkan pendapat yang diberikan siswa selama kelompok kecil, memang demikian Diketahui bahwa pembelajaran yang dilakukan dengan menggunakan model ini dapat memotivasi dan membantu siswa dalam belajar. Hasil revisi file prototipe 3 menghasilkan prototipe 4 .

Dan untuk kepraktisan digunakan rumus ini:

$$
N P=\frac{R}{S M} \times 100 \%
$$

Tabel 2 Hasil Praktikalitas Evaluasi Kelompok Kecil

\begin{tabular}{|c|l|c|c|}
\hline No & \multicolumn{1}{|c|}{ Aspek Dinilai } & $\begin{array}{c}\text { Nilai Persen } \\
(\mathbf{P})\end{array}$ & $\begin{array}{c}\text { Kriteria } \\
\text { Kepraktisan }\end{array}$ \\
\hline 1 & Kemudahan penggunaan & 85 & Tinggi \\
\hline 2 & Efisiensi waktu & 93 & Sangat Tinggi \\
\hline 3 & Manfaat & 83 & Tinggi \\
\hline \multicolumn{2}{|c|}{ Rata-rata } & 87 & Sangat Tinggi \\
\hline
\end{tabular}

Pada penelitian (Bruce Joyce, Marsha Weil, 2011) menyatakan bahwa model pembelajaran merupakan suatu perencanaan atau suatu pola yang digunakan sebagai pedoman dalam merencanakan pembelajaran di kelas. Model pembelajaran yang baik harus memiliki 5 unsur utama, yaitu; 1) tahapan (sintaks), 2) sistem sosial, yaitu ada hubungan atau interaksi antara guru dan siswa, 3) prinsip reaksi, yaitu bagaimana guru memperhatikan dan memperlakukan peserta didik, 4) sistem pendukung, yaitu kondisi yang dibutuhkan oleh suatu model (kemampuan dan fasilitas teknis), dan 5)dampak instruksional dan dampak pengiring. Model inkuiri terbimbing dan pendekatan flipped classroom yang dikembangkan dapat dikatakan sebagai model pembelajaran karena model tersebut memenuhi lima unsur tersebut.

Model pembelajaran yang dikembangkan adalah pembelajaran inkuiri terbimbing yang disajikan dalam bentuk flipped classroom. Pembelajaran ini mengandung dua pengaturan, yaitu synchronous dan asynchronous. Pembelajaran asinkron dilaksanakan pada tahapan persiapan, orientasi, dan eksplorasi dan pembentukan konsep. Sedangkan pembelajaran sinkron dilakukan pada tahap penerapan dan penutupan. Tahap asinkron dilakukan dengan menggunakan LMS Edmodo, sedangkan tahap sinkron dilakukan dengan menggunakan zoom meeting. Dengan adanya model inkuiri terbimbing dan pendekatan flipped classroom ini akan membuat proses belajar lebih terarah serta efektif dan praktis untuk dilakukan selama pandemi dan kondisi khusus lainnya yang mengharuskan pembelajaran dilakukan secara online dan juga dapat mendukung pembelajaran di era 4.0.

Dari tabel 1 dapat dilihat hasil validitas model inkuiri terbimbing dan pendekatan flipped classroom pada materi sifat koligatif larutan untuk siswa kelas XII SMA/MA. oleh para ahli, diperoleh nilai $\mathrm{V}=0,81$ dalam kategori valid. Hal ini menunjukkan bahwa model yang dikembangkan valid dari segi kelayakan konten, kelayakan konstruksi, bahasa dan grafik.

Dari segi kelayakan isi, Model ini memiliki rata-rata V 0,78 dalam kategori valid. Artinya, orientasi yang disampaikan melalui video sesuai dengan materi yang diajarkan, model (gambar, tabel, dll) yang digunakan untuk pertanyaan kunci sesuai dengan materi yang diajarkan, benar secara ilmiah, dan dapat dieksplorasi untuk menjawab pertanyaan kunci. Pertanyaan kunci yang terdapat dalam tahap eksplorasi 
1035 Integrasi Model Inkuiri Terbimbing Dan Pendekatan Flipped Classroom Pada Pembelajaran Materi Sifat Koligatif Larutan Untuk Siswa Kelas XII SMA/MA - Wilda Putri Waer, Mawardi Mawardi DOI: https://doi.org/10.31004/edukatif.v3i3.498

(dalam Edmodo) dapat mengarahkan siswa untuk mengeksplorasi model, kombinasi model dengan pertanyaan kunci dapat membimbing siswa untuk menemukan konsep, dan latihan serta pertanyaan yang terkandung dalam Edmodo dapat memperkuat konsep.

Dari segi kelayakan konstruksi, model ini memiliki rata-rata V 0,86 dalam kategori valid. Artinya desain pembelajaran sudah bedasarkan siklus pembelajaran inkuiri terbimbing, aplikasi Edmodo yang telah disosialisasikan sebelumnya memudahkan siswa untuk mengakses pembelajaran; Video orientasi memiliki kualitas gambar dan suara yang jernih; penyajian pertanyaan disertai dengan model (gambar, tabel, dll.) memudahkan siswa pada tahap eksplorasi; pertanyaan kunci yang diberikan mulai dari yang sederhana hingga kompleks; Penyajian tahap aplikasi pada fitur kelompok kecil Edmodo memungkinkan siswa untuk berdiskusi antar anggota kelompok; dan tahap penutupan yang dilakukan secara langsung menggunakan aplikasi zoom meeting memungkinkan siswa untuk melakukan konfirmasi konsep yang diperoleh dengan guru secara langsung.

Dari segi bahasa, model ini memiliki rata-rata nilai V 0,78 dalam kategori valid. Artinya bahasa yang digunakan pada video orientasi valid, dan bahasa yang digunakan pada pertanyaan kunci adalah bahasa yang baik dan benar menurut aturan pengejaan bahasa Indonesia.

Dari segi grafis, model inkuiri terbimbing dan pendekatan flipped classroom ini memperoleh nilai $\mathrm{V}$ 0,83 dalam kategori valid ini menunjukkan bahwa model (gambar, tabel, dll.) yang disajikan di Edmodo dapat diamati dengan jelas.

Model inkuiri terbimbing dan pendekatan flipped classroom pada materi sifat koligatif larutan yang dikembangkan memiliki kategori sangat tinggi dari segi kepraktisan siswa dan penilaian guru. Kepraktisan tanggapan siswa menunjukkan bahwa nilai $\mathrm{P}$ rata-rata yang diperoleh adalah 87 dengan kategori sangat tinggi. Dari hasil yang diperoleh terlihat bahwa model inkuiri terbimbing dan pendekatan flipped classroom pada materi sifat koligatif larutan yang dikembangkan mudah digunakan oleh siswa dan guru.

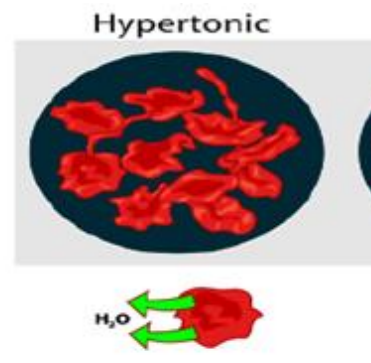

(a)

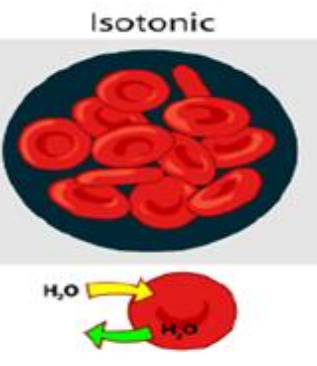

(b)

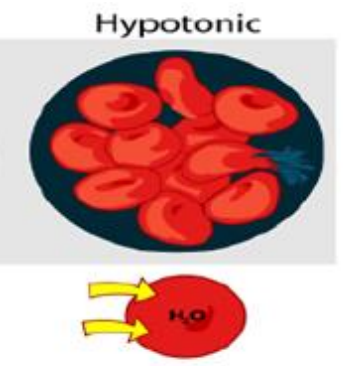

(c)

\section{Gambar 2. Salah Satu Representasi Kimia yang Digunakan dalam Pembelajaran}

Gambar 2 merupakan salah satu model yang diberikan untuk menjawab pertanyaan kunci pada saat siswa melakukan eksplorasi dan pembentukan konsep. Dimana disini siswa diharapkan mengetahui bahwa dalam kasus osmosis zat terlarut tidak dapat bergerak karena mereka tidak dapat melewati membran namun air dapat bergerak dan melewati membran ke arah daerah dengan konsentrasi zat terlarut yang lebih tinggi. hal ini menyebabkan masalah bagi sel seperti (Gambar 2a) sel menjadi dehidrasi karena air bergerak keluar sel, sebaliknya sel dapat menggembung dan pecah jika terlalu banyak air yang masuk kedalam sel seperti (Gambar 2c). Dari wawancara yang dilakukan dengan siswa didapatkan bahwa peristiwa osmosis dalam kehidupan sehari-hari yaitu pada sel darah dimana akan terjadinya perpindahan $\mathrm{H}_{2} \mathrm{O}$ berdasarkan konsentrasinya, hal ini dapat dilihat dari citra mikroskopis gambar tersebut. siswa juga dapat menemukan gambar yang dimaksud adalah sel darah yang mengalami peristiwa osmosis, berdasarkan simbol yang diberikan pada gambar 2 . Ketika siswa diharapkan menjawab pertanyaan kunci dengan benar, tidak hanya dengan menggunakan gambar yang dapat dilihat oleh mata (makroskopis), tetapi juga dari deskripsi simbol dan representasi mikroskopisnya. Karena ketika diberi gambar makroskopik saja, masih ada siswa yang menjawab gambar yang diberikan 
1036 Integrasi Model Inkuiri Terbimbing Dan Pendekatan Flipped Classroom Pada Pembelajaran Materi Sifat Koligatif Larutan Untuk Siswa Kelas XII SMA/MA - Wilda Putri Waer, Mawardi Mawardi

DOI: https://doi.org/10.31004/edukatif.v3i3.498

adalah donat, hal ini menunjukkan bahwa informasi makroskopik belum dapat membantu siswa dalam mencari konsep. Informasi sub-mikroskopis juga penting karena dengan melihat struktur zat, sifat-sifatnya dapat ditentukan. Dan lambang atau uraian suatu senyawa juga penting, disinilah tempatnya fungsi lambang adalah agar konsep yang ditemukan siswa utuh sehingga menjadi suatu kesimpulan yang tepat. Kombinasi dari ketiga komponen representasi kimia inilah yang membantu siswa menemukan konsep dalam dunia makroskopis, sub mikroskopis dan simbolik, tanpa ketiga hal tersebut siswa akan mengalami miskonsepsi, dan dengan bantuan representasi kimia, pembelajaran akan lebih bermakna (Sunyono et al., 2015).

Dari segi kemudahan penggunaan diperoleh nilai P rata-rata 85 dengan kategori kepraktisan tinggi. Ini menunjukkan bahwa Langkah-langkah pembelajaran berdasarkan model ini mudah dipahami. Selain itu, model (gambar, tabel, dll.) Dan pertanyaan kunci yang disediakan di Edmodo mudah dimengerti. Jadi ini juga menandakan bahwa bahasa yang digunakan di Edmodo juga mudah dimengerti.

Dari segi efisiensi waktu pembelajaran, model ini memiliki tingkat kepraktisan yang sangat tinggi dengan nilai $\mathrm{P}$ rata-rata 93. Hal ini menunjukkan bahwa dengan menggunakan model ini, siswa dapat belajar dengan kecepatannya masing-masing, sehingga menyebabkan waktu belajar menjadi lebih efisien.

Dari segi manfaat, model inkuiri terbimbing dan pendekatan flipped classroom pada materi sifat koligatif larutan ini memiliki tingkat kepraktisan yang sangat tinggi dengan nilai $\mathrm{P}$ rata-rata 83 . Hal ini menunjukkan bahwa Penggunaan model ini memudahkan siswa dalam memahami konsep sifat koligatif larutan. Model (gambar, tabel, dll.) Yang digunakan dalam Edmodo dapat membantu siswa menjawab pertanyaan kunci, sehingga dapat membimbing siswa memahami konsep. Di Edmodo, juga terdapat latihan dan soal yang dapat meningkatkan pemahaman siswa dalam memahami konsep sifat koligatif larutan, dan menggunakan model ini juga dapat meningkatkan minat dan aktivitas siswa dalam pembelajaran.

Salah satu alasan keberhasilan flip dalam pengaturan ini yaitu siswa dapat menjeda, memutar ulang, dan menonton ulang video pembelajaran, hal ini merupakan sesuatu yang tidak mungkin dilakukan bila pembelajaran dilakukan seperti biasanya seperti yang dikatakan (Fautch, 2015) pada kesimpulan penelitiannya. Model ini masih memiliki keterbatasan dimana pengaksesan LMS Edmodo melalui web tidak sestabil pengaksesan melalui aplikasi, sehingga siswa pengaksesan menggunakan aplikasi Edmodo lebih disarankan dibanding pengaksesan via web.

Berdasarkan uraian tersebut integrasi model inkuiri terbimbing dan pendekatan flipped classroom pada pembelajaran materi sifat koligatif larutan untuk siswa kelas XII SMA/MA dapat dikatakan valid dan praktis dengan nilai 0,81 kategori valid dan 87 dengan kategori sangat tinggi.

\section{KESIMPULAN}

Berdasarkan analisis data penelitian, dapat disimpulkan bahwa integrasi model inkuiri terbimbing dan pendekatan flipped classroom pada pembelajaran materi sifat koligatif larutan untuk siswa kelas XII SMA/MA, menunjukkan bahwa model ini valid dan praktis yang dibuktikan dengan hasil analisis validitas sebesar 0,81 pada kategori valid dan uji kepraktisan dengan nilai 87 pada kategori kepraktisan sangat tinggi.

\section{DAFTAR PUSTAKA}

Aini, F. Q., Fitriza, Z., Gazali, F., Mawardi, M., \& Priscylio, G. (2019). Perkembangan Model Mental Mahasiswa pada Penggunaan Bahan Ajar Kesetimbangan Kimia berbasis Inkuiri Terbimbing. Jurnal Eksakta Pendidikan (Jep), 3(1), 40. https://doi.org/10.24036/jep/vol3-iss1/323

Akkuzu, N., \& Uyulgan, M. A. (2017). Step by step learning using the i diagram in the systematic qualitative analyses of cations within a guided inquiry learning approach. Chemistry Education Research and Practice, 18(4), 641-658. https://doi.org/10.1039/c7rp00050b

Aumi, V., \& Mawardi, M. (2021). Validity And Practicity Of Flipped Guided Inquiry Based Learning (FGIL) Model In Chemical Kinetics For Year 1 Students. 4, 142-147. 
1037 Integrasi Model Inkuiri Terbimbing Dan Pendekatan Flipped Classroom Pada Pembelajaran Materi Sifat Koligatif Larutan Untuk Siswa Kelas XII SMA/MA - Wilda Putri Waer, Mawardi Mawardi DOI: https://doi.org/10.31004/edukatif.v3i3.498

Bruce Joyce, Marsha Weil, E. C. (2011). Models of Teaching (Eight Edition*). 478.

Chaeruman, U. A. (2019). Merancang Model Blended Learning Designing Blended Learning Model. Jurnal Teknodik, 17(4), 053. https://doi.org/10.32550/teknodik.v17i4.577

Danczak, S. M., Thompson, C. D., \& Overton, T. L. (2020). Development and validation of an instrument to measure undergraduate chemistry students' critical thinking skills. Chemistry Education Research and Practice, 21(1), 62-78. https://doi.org/10.1039/c8rp00130h

Fautch, J. M. (2015). The flipped classroom for teaching organic chemistry in small classes: Is it effective? Chemistry Education Research and Practice, 16(1), 179-186. https://doi.org/10.1039/c4rp00230j

Freeman, C., \& Herreid, N. A. S. (2013). Case Studies and the Flipped Classroom. Journal of College Science Teaching, 42(5), 62-66.

Hanson, D. M. (2005). Designing Process-Oriented Guided-Inquiry Activities. Faculty Guidebook - A Comprehensive Tool for Improving Faculty Performance, 1-6.

Kardena, H., \& Mawardi, M. (2020). Development of Guided Inquiry Based Student Worksheet for First College Student. International Journal of Scientific and Research Publications (IJSRP), 10(10), 375379. https://doi.org/10.29322/ijsrp.10.10.2020.p10650

Karyadi, P. A., Paristiowati, M., \& Afrizal, A. (2020). Analysis the 21St Century Skills of Students in Chemical Equilibrium Learning With Flipped Classroom-Collaborative Problem Solving Model. JTK (Jurnal Tadris Kimiya), 5(1), 48-60. https://doi.org/10.15575/jtk.v5i1.7971

Mawardi, M., Aisyah Fitri Rusiani, J., \& Yani, F. H. (2020). Effectiveness of student worksheets based guided inquiry on acid base material to improve students higher order thinking skill (HOTS). Journal of Physics: Conference Series, 1481(1). https://doi.org/10.1088/1742-6596/1481/1/012083

Nerantzi, C. (2020). The Use of Peer Instruction and Flipped Learning to Support Flexible Blended Learning During and After the COVID-19 Pandemic. International Journal of Management and Applied Research, 7(2), 184-195. https://doi.org/10.18646/2056.72.20-013

Nurhayati, R., Waluya, S. B., \& Asih, T. S. N. (2017). Model Pembelajaran Inkuiri Blended Learning Strategi Flipped Classroom dengan Media Interaktif untuk Meningkatkan Kemampuan Berpikir Kritis. Prosiding Seminar Nasionar Pascasarjana UNNES, 4.

Plomp, T., \& Nieveen, N. (2007). An Introduction to Educational Design Research.

Sunyono, Yuanita, L., \& Ibrahim, M. (2015). Supporting Students in Learning with Multiple Representation to Improve Student Mental Models on Atomic Structure Concepts. 26(2), 104-125.

Watson, J., Powell, A., Staley, P., Patrick, S., Horn, M., Fetzer, L., Hibbard, L., Oglesby, J., Verma, S., Education, M., C, T. O. C.-I. N. B., Kuehn, B. L., Ed, D., Archibald, D., Barbour, M. K., Leary, H., Wilson, E. V., \& Ostashewski, N. (2020). Teacher education and K-12 online learning. INACOL, The International Association for K-12 Online Learning, July, 1-20. http://files.eric.ed.gov/fulltext/ED560788.pdf

Wijanarko, Y. (2017). Model Pembelajaran Make a Match Untuk Pembelajaran Ipa Yang Menyenangkan. Taman Cendekia: Jurnal Pendidikan Ke-SD-An, 1(1), 52. https://doi.org/10.30738/tc.v1i1.1579

Yani, F. H., Mawardi, M., Fitri, A., \& Js, R. (2019). The Effectiveness of Using Student Worksheet Based on Guided Inquiry toward the Student Learning Outcames in Buffer Solution Matrial. 58-62. 